\title{
PENCEGAHAN CARIES BAGI ANAK-ANAK DI RUMAH BELAJAR IDE-ID, TANGGA BUNTUNG PALEMBANG
}

\author{
Nita Nuraini ${ }^{1}$, Erie Agusta ${ }^{2}$ \\ 1,2Program Studi Pendidikan Biologi, Fakultas Keguruan dan Ilmu Pendidikan \\ Universitas Muhammadiyah Palembang \\ Email: nitanuraini26@gmail.com ${ }^{1}$, erieagusta1@ gmail.com²
}

\begin{abstract}
Abstrak: Kegiatan ini bertujuan untuk mengetahui 1) partisipasi anak-anak dalam upaya pencegahan caries, dan 2) memberikan pengetahuan tentang upaya pencegahan caries, mengingat lingkungan Palembang sangat banyak ditemukan makanan manis maupun asam, seperti cuka. Metode dan teknik pengabdian meliputi ceramah, dan video. Perilaku sebagai sasaran intervensi mempunyai 3 domain, yakni: pengetahuan, sikap dan tindakan. Kegiatan dimulai dengan survey lokasi dan sasaran, dilanjutkan dengan penyampaian materi, tanya jawab. Area gigi yang dibersihkan meliputi bagian atas, bawah, samping, dan lidah. Hasil kegiatan ini menjelaskan bahwa 1) seluruh peserta aktif mengikuti petunjuk dengan sangat antusias. dan 2) tindakan pencegahan lain yakni dengan merubah kebiasaan mengkonsumsi makanan manis dan asam secara berlebihan dan pemilihan pasta dan sikat gigi yang baik. Kesadaran menjaga kesehatan gigi dan mulut merupakan upaya pencegahan caries untuk memelihara dan mempertinggi derajat kesehatan diri. Kesimpulan dari kegiatan ini 1) partisipasi anak-anak di rumah belajar IDE-ID sangat aktif dan antusiasi, dan 2) informasi yang disampaikan kepada anak-anak di Rumah Belajar IDEID tentang upaya pencegahan caries diantaranya merubah kebiasaan mengkonsumsi makanan manis dan asam secara berlebihan, dan melakukan pemilihan pasta dan sikat gigi dengan benar.
\end{abstract}

Keywords: Caries, IDE-ID, Gigi

Abstract: This activity aims to find out 1) the participation of children in the effort to prevent caries, and 2) to provide knowledge about efforts to prevent caries, given that the Palembang environment is very much found in sweet and sour foods, such as vinegar. The methods and techniques of service include discourse, and videos. Behavior as the target of intervention has 3 domains, namely: knowledge, attitudes and actions. The activity began with a location and target survey, followed by the delivery of material, question and answer. The area of the tooth that is cleaned includes the top, bottom, sides and tongue. The results of this activity explained that 1) all active participants followed the instructions very enthusiastically. and 2) other precautions, namely by changing the habit of consuming sweet and acidic foods excessively and selecting good pasta and toothbrushes. Awareness of maintaining dental and oral health is an effort to prevent caries from maintaining and enhancing the degree of personal health. The conclusion of this activity is 1) the participation of children in IDE-ID learning houses is very active and enthusiastic, and 2) information conveyed to children in IDE-ID Learning Houses about efforts to prevent caries including changing the habit of consuming sweet and sour foods excessive, and make a selection of pasta and brush your teeth properly.

Kata kunci : Caries, IDE-Id, Tooth

\section{PENDAHULUAN}

Kesehatan semua anggota atau bagian tubuh merupakan hal paling penting dalam kehidupan manusia. Salah satunya adalah gigi dan mulut. Gigi dan mulut sangat penting untuk diperhatikan kebersihannya, karena kesehatan mulut merupakan cerminan kesehatan yang ada di dalamnya pula (gigi). Oleh karena itu kesehatan gigi dan mulut sangat penting untuk diperhatikan. Diperkirakan bahwa 90\% dari anak-anak usia sekolah di seluruh dunia dan sebagian besar orang dewasa pernah menderita karies. Karies gigi merupakan penyakit yang terdapat pada jaringan keras gigi yaitu email, dentin dan sementum yang mengalami proses kronis regresif. Karies menyerang jaringan keras gigi yang ditandai dengan adanya demineralisasi jaringan keras gigi yang kemudian diikuti oleh kerusakan bahan organiknya (Mitchell, 2014). Prevalensi karies tertinggi terdapat di Asia dan Amerika Latin dan prevalensi terendah terdapat di Afrika (The World Oral Health Report, 2003). Di Amerika Serikat, karies gigi merupakan penyakit kronis anak-anak yang sering terjadi dan tingkatnya 5 kali lebih tinggi dari asma. Karies 
merupakan penyebab patologi primer atas penanggalan gigi pada anak-anak.

Menurut hasil Riset Kesehatan Dasar Departemen Kesehatan (Riskesdas) tahun 2007, sebanyak $75 \%$ gigi masyarakat indonesia mengalami karies gigi (gigi berlubang). Menurut data dari pengurus besar PDGI (Persatuan Dokter Gigi Indonesia) menyebutkan bahwa sedikitnya $89 \%$ penderita gigi berlubang adalah anak-anak usia dibawah 12 tahun (Sariningsih, 2012). Perilaku kurang baik yang ditunjukkan oleh anak dalam upaya pencegahan karies gigi antara lain adalah kebiasaan anak mengkonsumsi makanan manis dan tidak diakhiri dengan menggosok gigi atau setidaknya berkumur dengan air putih, sehingga banyak anak yang mengalami karies gigi pada usia dini.

Hasil analisis lapangan dan wawancara menggambarkan bahwa di daerah Tangga Buntung terdapat rumah belajar yang didominasi oleh anak-anak usia 8 - 12 tahun yang mengalami karies gigi dengan ciri-ciri gigi berlubang, keropos, dan terdapat noda/plak. Ciri tersebut berkaitan dengan pola atau perilaku anak-anak di daerah tersebut yang gemar mengkonsumsi makanan manis seperti permen, gula-gula dan cokelat, serta cuka yang asam. Palembang sebagai kota dengan makanan khas pempek sering dikonsumsi bersama dengan cuka yang sifatnya asam, tidak terkecuali oleh anak-anak di rumah belajar Ide-ID. Hal inilah yang juga memicu banyak anak-anak mengalami gigi keropos. Konsumsi makanan secara rutin ini tidak diikuti oleh aktivitas menggosok gigi secara rutin pula, sehingga lama-kelamaan berdampak pada kesehatan gigi mereka dengan ditemukannya anak-anak yang menderita caries.

Karies gigi merupakan penyakit gigi dan mulut yang multifaktorial artinya adalah karies dapat terjadi apabila terdapat faktor penyebab yang saling berhubungan dan mendukung, yaitu host (gigi dan saliva), mikroorganisme, substrat, dan waktu (Casamassimo, Fields, McTigue, Nowak, 2013). Peranan orang tua sangat penting dalam upaya pencegahan caries terhadap anakanak mereka. Hal ini disebabkan karena dalam keluarga mempunyai pola kebiasan makan yang sama dan pemeliharaan kesehatan gigi yang sama pula (Chu, 2008). Orang tua, khususnya ibu yang tingkat pengetahuannya rendah mengenai pola makanan anak, kebersihan mulut anak dan pemeriksaan rutin ke dokter gigi menyebabkan resiko anaknya mempunyai karies gigi (Suresh et al., 2010).

Kegiatan sosialisasi pencegahan caries ini sangat penting dilakukan dalam rangka memberikan pengetahuan akan penyebab utama, cara penyebaran, dampak, dan upaya pencegahan caries di Tangga Buntung. Kebiasaan menjaga kesehatan gigi dan mulut serta upaya pelaksanaan pencegahan caries yang dilakukan seseorang menunjukkan bahwa orang tersebut memiliki kesadaran untuk memelihara dan mempertinggi derajat kesehatan diri sejak dini sehingga tidak terjadi gangguan fungsi, aktivitas (belajar dan bekerja) dan penurunan produktivitas kerja yang tentunya akan mempegaruhi kualitas hidup (Depkes, 1999).

Tujuan Kegiatan pengabdian kepada masyarakat ini, adalah: 1) mengetahui partisipasi anak-anak dalam upaya pencegahan caries untuk memelihara dan mempertinggi derajat kesehatan diri; 2) memberikan pengetahuan kepada anak-anak di Rumah Belajar Ide-ID, Tangga Buntung Palembang mengenai upaya pencegahan caries. Adapun manfaat atau kegunaan kegiatan pengabdian masyarakat ini adalah: 1) membentuk kesadaran anak-anak untuk memelihara dan mempertinggi derajat kesehatan diri; 2) melakukan pencegahan terjadinya caries pada anak-anak di Rumah Belajar Ide-ID, Tangga Buntung Palembang

Target khusus kegiatan ini adalah agar anak-anak mampu menyadari cara menjaga kesehatan gigi dan mulut sebagai bentuk pencegahan caries serta mengurangi konsumsi makanan dan minuman yang mampu mempercepat caries mengingat lingkungan Palembang sangat banyak ditemukan makanan manis maupun asam, seperti cuka yang sering dikonsumsi anak-anak.

Kemukakan tujuan program dan kegunaan program serta target dan luaran. [Times New Roman, 11, spasi 1.15].

\section{METODE PELAKSANAAN}

\section{A. Waktu dan Tempat Pelaksanaan}

Kegiatan Sosialisasi Pencegahan Caries dilaksanakan di Tangga Buntung Palembang di selama 2 hari.

\section{B. Metode dan Teknik Sosialisasi}

Metode dan teknik sosialisasi meliputi pelaksanaan promosi kesehatan dengan menggunakan berbagai metode berdasarkan kelompok sasaran. Sasaran kelompok kecil dan besar umumnya menggunakan metode ceramah, dibantu dengan slide, video. Kelompok kecil biasanya menggunakan metode ceramah, dapat juga menggunakan alat bantu slide, video, lembar balik dan sebagainya. Perilaku sebagai sasaran intervensi mempunyai 3 domain, yakni: pengetahuan (knowledge), sikap (attitude) dan 
praktek atau tindakan (practice). Pengetahuan dan sikap merupakan perilaku yang masih tertutup (covert behavior), sedangkan praktek atau tindakan merupakan perilaku yang sudah terbuka (overt behavior). Oleh sebab itu, perubahan perilaku sebagai hasil pendidikan atau promosi kesehatan terjadi secara bertingkat. Pemberian informasi melalui sosialisasi kesehatan sebagai bagian dari promosi kesehatan akan meningkatkan pengetahuan tentang kesehatan. Pengetahuan kesehatan akan meningkatkan sikap terhadap kesehatan, dan selanjutnya akan berakibat terhadap perubahan praktek hidup sehat (overt behavior) (Notoadmodjo 2008).

Adapun bentuk kegiatan pengabdian yang dilakukan adalah bentuk sosialisas pencegahan caries di Tangga Buntung Palembang. Susunan kegiatan sosialisasi adalah sebagai berikut:

1. Absensi dan pembukaan kegiatan sosialisasi.

2. Penyampaian materi dengan metode ceramah, dibantu dengan menggunakan slide dan video.

3. Pelaksanaan kegiatan menggosok gigi secara benar, sebagai upaya pencegahan caries.

4. Pengecekan kegiatan sosialisasi

5. Pemberian sikat dan pasta gigi bagi anakanak di Tangga Buntung Palembang

6. Penutupan.

\section{HASIL DAN PEMBAHASAN}

\section{A. Kegiatan Sosialisasi Pencegahan Caries dan Partisipasi Anak-anak}

Kegiatan pengabdian masyarakat ini dimulai dengan survey awal terkait lokasi dan sasaran pengabdian masyarakat dengan tema "Sosialisasi Pencegahan Caries Bagi Anak-Anak di Rumah Belajar IDE-ID, Tangga Buntung Palembang". Peserta yang terlibat dalam kegiatan ini mayoritas adalah anak-anak, tenaga pengajar, dan beberapa orang tua peserta (anak-anak). Kegiatan sosialisasi berjalan dengan baik, lancar dan disambut antusias oleh seluruh anak-anak karena berkaitan erat dengan anggota tubuh langsung. Penyampaian materi dibantu langsung oleh dokter gigi yang ahli dibidangnya dengan bantuan powerpoint dengan menampilkan gambar dan contoh yang menarik. Penyampaian materi dilakukan kurang lebih sekitar 15 menit, lalu dilanjutkan dengan penjelasan anatomi gigi manusia menggunakan poster dan dilanjutkan dengan kegiatan tanya jawab.

Materi sosialisasi meliputi penyebab utama caries gigi, cara penyebaran caries, dampak caries, dan upaya pencegahan yang dapat dilakukan untuk menghindari terjadinya caries gigi. Caries gigi atau gigi berlubang adalah suatu penyakit padajaringan keras gigi yangditandai oleh rusaknya email dan dentin disebabkan oleh aktivitas metabolisme bakteri dalam plak yang menyebabkan terjadinya demineralisasi akibat interaksi antar produk-produk mikroorganisme, ludah dan bagian-bagian yang berasal dari makanan dan email. Caries adalah salah satu penyakit yang paling banyak di jumpai di sekitar masyarakat, dan menjadi bukti nyata bahwa kurangnya kesadaran masyarakat dalam merawat kesehatan gigi dan mulut.

Penyebab utama terjadinya caries terdiri atas 4 faktor yang terjadi secara bersamaan, meliputi: gigi sebagai tuan rumah (host), substrat seperti makanan, plak atau kuman dan waktu. Faktor penting lainnya yang juga berdampak pada kesehatan gigi dan mulut adalah lingkungan, perilaku, pelayanan kesehatan dan keturunan (Hereditas). Perilaku masyarakat terutama anak-anak berperan penting dalam mempengaruhi status kesehatan gigi mereka. Kecenderungan yang baik dalam menjaga kesehatan gigi dan mulut akan berdampak baik pula terhadap kesehatan gigi, sedangkan perilaku buruk dalam menjaga kesehatan gigi dan mulut akan memperbesar kemungkinan terjadinya caries gigi.

Caries gigi terjadi disebabkan karena serangkaian proses yang terjadi selama beberapa kurun waktu dengan 3 tiga faktor utama lain yang saling mendukung, yaitu host atau gigi, mikroorganisme, substrat dan waktu. Caries ini merupakan penyakit yang umum ditemui karena kebiasaan anak-anak yang tidak menggosok gigi dan membersihkan gigi setelah mengkonsumsi makanan, sehingga sisa makanan yang menumpuk menjadi pemicu caries terjadi. Dukungan dan peranan orang tua sangat berpengaruh terhadap perilaku pencegahan caries pada anak-anak, misalnya dengan memberikan contoh menggosok gigi setelah makan dan sebelum tidur.

Pemateri juga mengajarkan kepada anakanak bagaimana cara menggosok gigi dengan baik dan benar dengan memberi contoh langsung serta menampilkan poster anatomi gigi untuk melihat bagian-bagain yang perlu dan penting untuk dibersihkan. Setelah pemateri memberi contoh, kemudian seluruh peserta mengikuti dan mempraktekan cara menggosok gigi dengan baik dan benar untuk diterapkan dalam kehidupan sehari-hari. Peserta sosialisasi yang terdiri dari anak-anak, orang dewasa dan orang tua, sebagian besar merasa tertarik dengan materi caries yang disampaikan oleh dokter gigi secara langsung, 
karena menurut mereka penyakit ini sangat sering dijumpai disekitar mereka dan berhubungan erat dengan anggota tubuh mereka. Menurut salah satu pengurus rumah belajar, banyak anak-anak yang mengalami caries gigi karena kurangnya perhatian orang tua dan kendala ekonomi yang menyebabkan kurangnya pemerikasaan gigi bagi anak-anak.

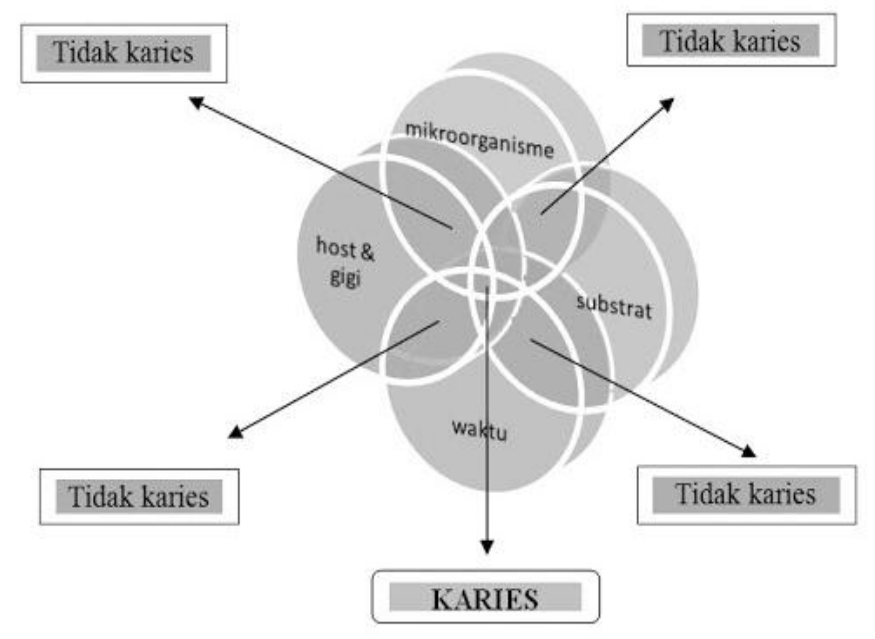

Gambar 4.1. Faktor Penyebab Caries Gigi

(Sumber: http://akbaranthonie.blogspot.com/2013/02/ analisis-karies-gigi-molar-pertama.html)

\section{B. Upaya Anak-anak di Rumah Belajar Ide-ID dalam Mencegah Caries}

Kegiatan penyampaian materi yang telah dilakukan oleh dokter gigi dilanjutkan dengan kegiatan tanya jawab. Antusiasme anak-anak dan pengajar di Rumah Belajar Ide-ID sangat tinggi, hal ini terlihat dari banyaknya siswa yang bertanya seputar ciri-ciri gigi yang sehat, penyakit gigi serta tindakan yang perlu dilakukan apabila terserang berbagai penyakit gigi. Terakhir, kegiatan dilanjutkan dengan praktek menggosok gigi dengan bai dan benar. Pengajaran tentang cara menggosok gigi ini dianggap perlu sebagai bentuk atau upaya pencegahan terhadap penyakit caries. Pada saat kegiatan ini, seluruh anak-anak, pengajar dan orang tua aktif mengikuti petunjuk yang diberikan oleh dokter gigi dengan sangat antusias. Area gigi yang dibersihkan meliputi bagian atas, bawah, samping, dan lidah. Aturan penggunaan pasta gigi dan pemilihan sikat gigi yang tepat juga disampaikan kepada para peserta. Tindakan pencegahan lain juga dapat dilakukan dengan merubah kebiasaan mengkonsumsi makanan manis dan asam secara berlebihan.

Kebiasaan menjaga kesehatan gigi dan mulut serta upaya pelaksanaan pencegahan caries yang dilakukan seseorang menunjukkan bahwa orang tersebut memiliki kesadaran untuk memelihara dan mempertinggi derajat kesehatan diri sejak dini sehingga tidak terjadi gangguan fungsi, aktivitas (belajar dan bekerja) dan penurunan produktivitas kerja yang tentunya akan mempegaruhi kualitas hidup (Depkes, 1999). Kegiatan pengabdian masyarakat ini juga diharapkan mampu memberikan pemahaman dan pengalaman belajar bagi anak-anak dan para orang tua untuk mendukung pencegahan caries. Berdasarkan penjelasan di atas, dapat disimpulkan bahwa upaya pencegahan yang dapat dilakukan untuk mencegah terjadinya caries gigi, antara lain:

1. Menyikat gigi secara teratur (minimal dua kali sehari, yaitu pada pagi hari setelah sarapan dan malam hari sebelum tidur)

2. Memperhatikan pola makan

3. Melakukan kunjungan ke dokter gigi secara rutin.

4. Mengontrol dan mengindari kebiasaan makan yang buruk (makan makanan manis atau asam secara berlebihan

5. Tindakan sosialisasi juga sangat diperlukan sebagai langkah awal upaya pencegahan penyakit caries, karena kegiatan tersebut dapat membantu masyarakat dalam memperoleh informasi atau pengetahuan tentang penyakit caries.

\section{SIMPULAN DAN SARAN}

\section{A. Simpulan}


Kegiatan pengabdian masyarakat di Rumah Belajar Ide-ID Tangga Buntung Palembang dapat disimpulkan sebagai berikut:

1. Kegiatan pengabdian masyarakat dilakukan dengan memberikan informasi kepada peserta di Rumah Belajar Ide-ID (anakanak, pengajar dan orang tua) tentang penyebab utama caries, cara penyebaran, dampak, dan upaya pencegahan caries.

2. Upaya pencegahan caries yang dapat dilakukan peserta pengabdian masyarakar antara lain: menggosok gigi secara teratur, memperhatikan pola makan, melakukan kunjungan ke dokter gigi secara rutin, mengontrol dan mengindari kebiasaan makan yang buruk (makan makanan manis atau asam secara berlebihan

3. Kegiatan sosialisasi pencegahan caries gigi ini diharapkan mampu memberikan manfaat bagi masyarakat serta kesadaran untuk menjaga kesehatan gigi dan mulut sebagai upaya memelihara dan mempertinggi derajat kesehatan untuk kualitas hidup yang lebih baik.

\section{B. Saran}

Menjaga kebersihan gigi dan mulut merupakan langkah awal untuk meminimalisir penyakit caries, oleh karena itu sangat perlu bimbingan dan arahan dari para orang tuaagar anak-anak terhindar dari caries gigi.

\section{UCAPAN TERIMAKASIH}

Terimakasih kepada Lembaga Penelitian dan Pengabdian Masyarakat (LPPM) Universitas Muhammadiyah Palembang yang telah memberikan dana kegiatan Pengabdian Mayarakat ini.

\section{DAFTAR PUSTAKA}

Arisman. 2004. Gizi dalam Daur Kehidupan. Jakarta: EGC.

Asse, R. 2010. Kesehatan Gigi dan Dampak Sosialnya. Diakses dari http://kesehatan.kompasiana.com/medis/ 2010/11/23/kesehatan-gigi-dandampaksosialnya-catatan-dari-maratua-320506.

Begzati, A., Berisha, M., Meqa, K. 2010. Early Childhood Caries in Preschool Children of Kosovo a Serious Public Health Problem. BMC Public Health. Diakses dari http://www.biomedcentral.com/14712458/10/788.
Brown, JP and Dodds, MWJ. 2008. Dental Caries and Associated Risk Factors. In: Cappelli DP and Mobley CC. Prevention and Clinical Oral Health Care. Missuori: Mosby Elsevier.

Casamassimo, PS., Fields, HW., Mc Tigue, DJ., Nowak, AJ. 2013. Pediatric Dentistry: Infancy Through Adolescence Fifth Edition. Missouri: Elsevier.

Chu S. 2008. Riview - Early Childhood Caries: Risk and Prevention in Underserved Population. Diakses dari http://www..jyi.org/research/ re.php?id=717.

Depkes RI. 1999. Profil Kesehatan Gigi dan Mulut di Indonesia pada Pelita VI. Jakarta: Direktorat Kesehatan Gigi, Depkes RI.

Heriandi, S. 2002. Penanggulangan Karies Rampan serta Keluhannya pada anak. FKG. Jakarta: UI.

Kumala P, dkk. 2006. Kamus Saku Kedokteran Dorland. Jakarta; EGC.

Mitchell, L. 2014. Kedokteran Gigi Klinik: Semua Bidang Kedokteran Gigi. Edisi 5. Jakarta: EGC.

Notoadmodjo, S. 2011. Kesehatan Masyarakat Ilmu dan Seni Edisi Revisi. Jakarta: Rineka Cipta.

RISKESDAS/Riset Kesehatan Dasar. 2007. Jakarta: Badan Penelitian dan Pengembangan Kesehatan, Departemen Kesehatan, Republik Indonesia.

Sariningsih, E. 2012. Merawat Gigi Anak Sejak Usia Dini. Jakarta: Elex Media Komputindo.

Suresh, B. S., Ravishankar, T. L., Chaitra, T. R., Mohapatra, A. K., Gupta, V. 2010. "Mother Knowledge about pre-school Child's oral Health". Journal of Indian Society of Pedodontics and Preventive Dentistry. Vol. 28, No 4, 282- 287.

The World Oral Health Report. 2003. Continuous Improvement of Oral Health in the $21^{\text {st }}$ Century-the approach of the WHO Global Oral health Programme. Diakses dari the World Health Organization. (file in pdf). http://www.who.int. 